\title{
IbM KELOMPOK USAHA BERSAMA "MAJU" DAN "SEJATI" DESA TENGAH DALAM PEMANFAATAN POTENSI BUAH SRIKAYA UTAN
}

\section{Didi Suwardi, M.Sc \\ Dinar Suksmayu Saputri, M.P dan Fitria PermataCita, ME Universitas Teknologi Sumbawa}

\section{- Latar Belakang Masalah Penelitian}

Ketersedian buah Annona squamosa Linn atau srikaya sangat melimpah di Kecamatan Utan dan belum dimanfaatkan oleh masyarakat menjadi aneka makanan yang bernilai secara ekonomi. Kurangnya Pemahaman kelompok mitra dalam manajemen usaha

- Metode Penelitian

1. Sosialisasi dan Perijinan Pengabdian

2. Pelatihan dan pendampingan membuat bisnis plan

\section{- Tujuan dan Luaran Pengabdian}

1. Memberikan pelatihan kepada kelompok mitra

2. Meningkatnya pengetahuan dan ketrampilan kelompok mitra dalam mengelolah usahanya

- Tempat, Waktu dan Sasaran Penelitian

Tempat: Desa Tengah Kecamatan Utan Kabupaten Sumbawa, NTB

Waktu : Juli-Oktober 2017

Sasaran : Kelompok Usaha Bersama

"Maju" dan "Sejati"

\section{- Hasil Penelitian}

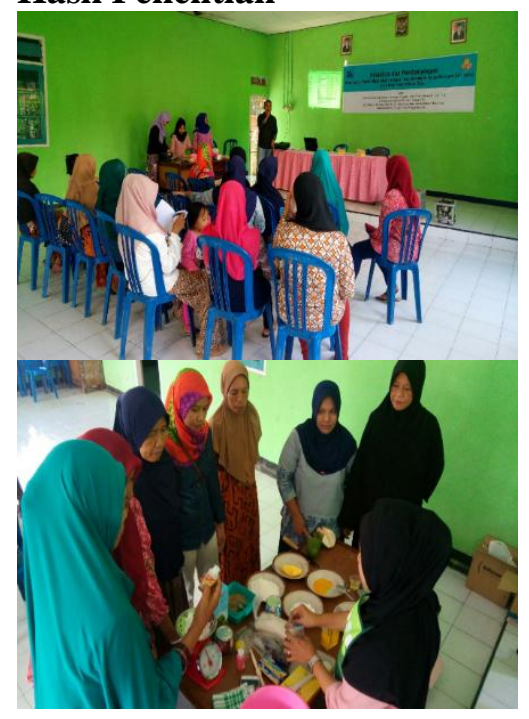

3. Pelatihan dan pendampingan pembukuan

4. Pelatihan dan pendampingan membuat aneka makanan berbahan baku buah "Srikaya"

3. Meningkatnya pengetahuan dan ketrampilan kelompok mitra dalam membuat aneka makanan berbahan baku buah lokal "Srikaya"

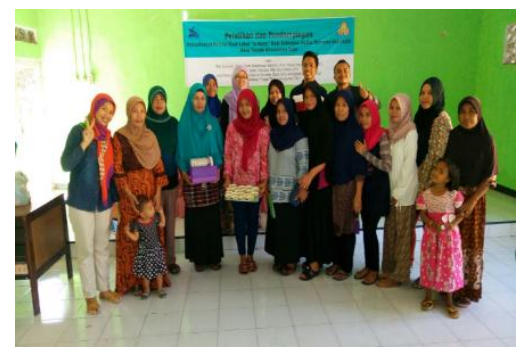

80\% anggota kelompok mitra aktif dalam kegiatan pelatihan Bisnis Plan dan pelatihan membuat aneka makanan dari buah srikaya

\section{- Kesimpulan}

Kelompok mitra (Kelompok Usaha Bersama Maju dan Sejat) aktif dalam mengikuti kegiatan pelatihan dan memahami bagaimana cara menyusun Bisnis Plan dan membuat Aneka makanan dari buah srikaya.

sesudah adanya kredit modal usaha BMT berkisar antara Rp.726.020-Rp.9.058.756 dengan rata-rata Rp.3.803.203 serta selisih ratarata yang diperoleh sebesar Rp1.202.424 atau meningkat sebesar 18,78\%. Dari perbedaan pendapatan tersebut dapat disimpulkan bahwa dengan adanya pemberian kredit modal usaha BMT terhadap rumah tangga miskin dapat dikatakan meningkatkan pendapatan rumah tangga miskin. Besar pendapatan bersih dari 
JURNAL TAMBORA Vol 2 № 3 Desember 2017 